\title{
PENDIDIKAN KARAKTER MELALUI PEMBELAJARAN MATEMATIKA
}

\author{
Erik Santoso ${ }^{1}$ \\ ${ }^{1}$ Fakultas Keguruan dan Ilmu Pendidikan, Universitas Majalengka \\ eriksantoso@unma.ac.id
}

\begin{abstract}
Abstrak-Pendidikan karakter menjadi isu hangat diberbagai negara dan menjadi perhatian serius. Hal ini juga dirasakan di Indonesia penerpan pendidikan karakter menjadi prioritas penting dalam pembelajaran. 18 karakter dapat menjadi rujukan oleh guru dalam mengembangkan pendidikan karakter dalam proses pembelajaran. Guru matematika memiliki peranan penting dalam mengembangkan pendidikan karakter melalui pembelajaran di kelas. Metode penelitian digunakan dalam pembahasan topik utama dalam artikel ini menggunakan model analisis kausal efektual dengan menggunakan pendekatan rasional yang dirangkai berdasarkan hasil kajian pustaka (literature review). Melalui kajian dan analisis dengan penelaahan secara mendalam kajian teori maka pembelajaran matematika bisa menumbuhkan karakter pada diri siswa. Karakter diperlukan agar siswa mampu menjadi manusia yang cerdas dan baik. Selain itu karakter juga diperlukan sebagai modal dalam menghadapi era digital dengan persaingan yang ketat. Pembelajaran matematika bisa menjadi sarana dalam membiasakan pendidikan karakter yaitu melalui pembelajaran yang didalamnya diberikan soal pemecahan masalah. Pemberian karakter ini diharapkan menjadi kebiasaan dalam diri siswa sehingga siswa memiliki karakter yang baik.
\end{abstract}

Kata kunci: pendidikan karakter, pembelajaran matematika 


\section{PENDAHULUAN}

Pendidikan pada hakekatnya harus diberikan pada setiap manusia. Hal ini didasarkan pada Undang Undang Negara Republlik Indonesia bahwa hak dasar yang harus ada di setiap orang di Indonesia adalah hak untuk mendapat pendidikan. Oleh karena itu, pemerintah mewajibkan pendidikan di Indonesia mulai dari 9 tahun sampai dengan 12 tahun. Kendati demikian, di lapangan tidak semudah apa yang dibayangkan, dikarenakan masih banyak orang di Indonesia yang masih kesulitan dalam mengenyam pendidikan. Pendidikan pada hakikatnya bertujuan untuk merubah moral dan pengetahuan. Hal ini sesuai dengan pendapat (Sudrajat, 2011), sepanjang sejarahnya, di seluruh dunia ini, pendidikan pada hakikatnya memiliki dua tujuan, yaitu membantu manusia untuk menjadi cerdas dan pintar (smart), dan membantu mereka menjadi manusia yang baik (good). Berkaitan dengan hal tersebut ada dua tujuan utama bagi guru dalam memberikan pembelajaran yaitu membuat siswa baik secara moral dan membuat siswa menjadi cerdas akan pengetahuan yang didapatnya.

Pendidikan moral merupakan isu yang hangat dalam pembelajaran menuju generasi emas yang dicanangkan Indonesia sebagai bentuk menyambut 100 tahun kemerdekaan Indonesia yaitu tahun 2045. Permasalahan moral atau yang lebih di kenal dengan karakter merupan jalan untuk mewujudkan generasi emas tersebut. Suyata (2011: 13), dalam sepuluh sampai dua puluh tahun lalu, istilah pendidikan moral lebih populer di Amerika, sedang istilah pendidikan karakter lebih popular di di kawasan Asia. Perlu langkah yang sinergis dari pusat sampai daerah untuk mempersipkan generasi emas ini yang memiliki karakter yang kuat.
Beberapa faktor yang dapat kita amati mengapa pendidikan karakter atau pendidikan moral masih perlu menjadi perhatian untuk pendidikan Indonesia. Hal ini ditandai dengan adanya gesekan sosial yang dilakukan siswa masih dapat kita jumpai, misalkan tawuran perayaan kelulusan ujian nasional dengan hura hura dan lain sebagainya. Beberapa hal yang menjadi pemicunya adalah lingkugan yang kurang mendukung. Hal ini disampaikan Ramdhani (2017) implementasi pendidikan karakter sangat dipengaruhi oleh lingkungan pendidikan. Lingkungan utama memang ada di keluarga tetapi sekolah punya peran penting dalam mewujudkan pendidikan yang berkarakter untuk siswanya. Ketika menyangkut sekolah maka peran guru menjadi penting dalam mengimplementasikan pendidikan karakter untuk siswanya. Termasuk guru matematika di dalamnya.

Secara harfiah matematika erat kaitannya dengan bilangan dan ruang. Hal ini sesuai dengan pendapat Mathematics is the abstract study of topics such as quantity (numbers) (Cook, 2011), structure, space (Cook, 2011) and change (Csicsery, 2008), (Devlin, 2012). Matematika memiliki peranan penting dalam pengembangan sumber daya manusia dan perkembangan teknologi. Hal ini ditandai dengan perkembangan teknologi yang dasar pengembangannya dari matematika. Perlu sinergitas antara guru dan sekolah agar pembelajaran matematika bisa memberikan penguatan karakter di dalamnya. Hal ini dikarenakan setiap guru terhubung langsung melalui pembelajaran dengan siswanya.

Penyelengaraan pendidikan karakter yang diselenggarakan dalam sistem pendidikan disebuah negara akan berbeda dengan negara lainnya, 
karena sistem pendidikan yang diselenggarakan diberbagai negara mempunyai ciri yang sesuai dengan latar belakang negara masing-masing Farida (2016). Indonesia sudah jauh jauh hari menerpakan pendidikan karakter dalam tujuan pendidikan nasional. Oleh karena itu perlu adanya sinergitas yang tinggi antara pusat dan daerah dalam mengelola pendidikan sehingga pendidikan karakter bisa terwujud dan menjadikan Indonesia menjadi negara dengan sumber daya manusianya yang bermoral.

\section{METODE PENELITIAN}

Model analisis yang digunakan dalam pembahasan topik utama dalam artikel ini menggunakan model analisis kausal efektual dengan menggunakan pendekatan rasional yang dirangkai berdasarkan hasil kajian pustaka (literature review) Ramdhani (2017). Kemudian didukung juga oleh pendapat bahwa metode yang digunakan dalam penulisan literatur review ini adalah dengan penelusuran yang bersumber dari electronic (Fahmi, dan Hidayati, 2016).

Metode ini dengan jelas membuat analisis pemabahasan topik utama dengan pendekatan yang rasional berdasarkan hasil kajian pustaka. Oleh karena itu metode ini memberikan pandangan dan paparan dari penulis mengenai topik utama yang disampaikan.

\section{HASIL DAN PEMBAHASAN Desain Pendidikan Karakter}

Farida, (2016) Karakter merupakan nilai-nilai perilaku manusia yang berhubungan dengan Tuhan Yang Maha Esa, diri sendiri, sesama manusia, lingkungan dan kebangsaan yang terwujud dalam pikiran, sikap, perasaan, perkataan, dan perbuatan berdasarkan norma- norma agama, hukum, tata krama, budaya dan adat istiadat. Berdasarkan pendapat tersebut bahwa setiap karakter berhubungan baik antara manusia dengan tuhan maupun manusia dengan manusianya sendiri. Hal yang penting dalam melaksanakan pendidikan karakter adalah pembiasaan. Pembiasaan merupakan kunci agar karakter tersebut dapat terus menerus dilaksanakan dalam kehidupan seharihari. Pembiasaan membuat karakter yang memang sudah tertanam dalam diri seseorang bukan diada ada karena situasi tertentu. Beberapa pendekatan desain pembiasaan diantaranya: pembiasaan dalam pemikiran (habits of the mind), dan pembiasaan dalam persaan (habits of the heart), dan pembiasaan dalam tindakan (habit of the action) (Zubaedi, 2011).

Pembiasaan dalam tindakan perlu dilakukan agar siswa dapat menerapkan karakter itu dalam kehidupan sehari hari. Perlu penguatan dari agar pembiasan ini dapat terlaksana dengan baik. Pembiasaan tindakan seseorang akan berdampak pada kelompok masyarakat, dan akan berakibat pula pada masyarakat yang lebih luas lagi bahkan sampai negara. Contoh jepang merupakan negara yang memegang teguh disiplin setiap orangnya, sehingga berdampak pada negara Jepang menjadi negara maju dan terdepan secara teknologi karena warganya memiliki disiplin yang kuat. Itulah pentingnya pendidikan karakter dalam bentuk pembiasaan tindakan sehari-hari.

\section{Strategi Pendidikan Karakter}

Strategi pelaksanaan pendidikan karakter yang diterapkan di sekolah dapat dilakukan melalui empat cara, yaitu: (1) pembelajaran (teaching), (2) keteladanan (modeling), (3) penguatan (reinforcing), dan (4) pembiasaan (habituating) (Sudrajat, 2011). Melalui keempat itu secara bertahap pendidikan karakter dapat diterapkan 
pada siswa. Keteladanan perlu diterapkan agar siswa dapat mencontoh pada gurunya. Pembelajaran menjadi kunci dalam menerapkan pendidikan karakter dan itu bisa dilakukan oleh guru matematika.

Strategi implementasi pendidikan karakter dapat ditempuh dengan berbagai pendekatan, Amri, dan Elisah (2011) memberikan penjelasan tentang pendekatan implementasi pendidikan karakter, yaitu:

1. Pendekatan penanaman nilai Pendekatan penanaman nilai (inculcation approach) ialah suatu pendekatan yang menitikberatkan pada penanaman nilai-nilai sosial agar mampu terinternalisasi dalam diri peserta didik. Metode pembelajaran yang dapat digunakan saat menerapkan penanaman nilai pada peserta didik diantaranya melalui keteladanan, pengautan sikap positif dan negatif, simulasi, bermain peran, tindakan sosial, dan lain-lain

2. Pendekatan

kognitif

perkembangan

perkembangan

Pendekatan memandang bahwa peserta didik merupakan individu yang memiliki potensi kognitif yang sedang dan akan terus tumbuh dan berkembang. Karena itu, melalui pendekatan ini peserta didik didorong untuk membiasakan berfikir aktif tentang seputar masalah-masalah moral yang hadir di sekeliling mereka, dimana peserta didik dilatih untuk belajar dalam membuat keputusankeputusan moral. Pada gilirannya diharapkan keputusan yang diambilnya dapat melatih peserta didik untuk bertanggungjawab terhadap keputusan yang diambilnya.
3. Pendekatan klarifikasi nilai Orientasi pendekatan klarifikasi nilai ialah memberikan penekanan untuk membantu peserta didik mengkaji perasaan dan perbuatannya sendiri, kemudian secara bertahap ditingkatkan kemampuan kesadaran peserta didik terhadap nilai-nilai yang didefinisikan sendiri oleh peserta didik.

4. Pendekatan pembelajaran berbuat Karakteristik pendekatan pembelajaran berbuat berupaya menekankan pada usaha pendidik untuk memfasilitasi dengan memberikan kesempatan pada peserta didik untuk melakukan perbuatan-perbuatan moral yang dilakukan secara individual maupun berkelompok.

Melalui strategi pendidikan karakter tersebut perlu adanya keselarasan secara keseluruhannya agar dapat berjalan dengan baik. Hal ini didasarkan agar pendidikan karakter yang dilakukan oleh guru dapat dirasakan secara maksimal.

Pembelajaran Matematika Melalui Penyisipan Pendidikan Karakter

Nilai-nilai yang ditanamkan dan dikembangkan pada sekolah-sekolah di Indonesia beserta deskripsinya adalah sebagai berikut:

1. Religius. Sikap dan perilaku patuh dalam melaksanakan ajaran agama yang dianutnya, toleran terhadap pelaksanaan ibadah agama lain, dan hidup rukun dengan pemeluk agama lain.

2. Jujur. Perilaku yang didasarkan pada upaya menjadikan dirinya sebagai orang yang selalu dapat dipercaya dalam perkataan, tindakan, dan pekerjaan.

3. Toleransi. Sikap dan tindakan yang menghargai perbedaan agama, suku, etnis, pendapat, sikap, dan 
tindakan orang lain yang berbeda dari dirinya.

4. Disiplin. Tindakan yang menunjukkan perilaku tertib dan patuh pada berbagai ketentuan dan peraturan.

5. Kerja Keras. Perilaku yang menunjukkan upaya sungguhsungguh dalam mengatasi berbagai hambatan belajar dan tugas, serta menyelesaikan tugas dengan sebaikbaiknya.

6. Kreatif. Berpikir dan melakukan sesuatu untuk menghasilkan cara atau hasil baru dari sesuatu yang telah dimiliki.

7. Mandiri. Sikap dan perilaku yang tidak mudah tergantung pada orang lain dalam menyelesaikan tugas-tugas.

8. Demokratis. Cara berfikir, bersikap, dan bertindak yang menilai sama hak dan kewajiban dirinya dan orang lain.

9. Rasa Ingin Tahu. Sikap dan tindakan yang selalu berupaya untuk mengetahui lebih mendalam dan meluas dari sesuatu yang dipelajarinya, dilihat, dan didengar.

10. Semangat Kebangsaan. Cara berpikir, bertindak, dan berwawasan yang menempatkan kepentingan bangsa dan negara di atas kepentingan diri dan kelompoknya.

11. Cinta Tanah Air. Cara berfikir, bersikap, dan berbuat yang menunjukkan kesetiaan, kepedulian, dan penghargaan yang tinggi terhadap bahasa, lingkungan fisik, sosial, budaya, ekonomi, dan politik bangsa.

12. Menghargai Prestasi. Sikap dan tindakan yang mendorong dirinya untuk menghasilkan sesuatu yang berguna bagi masyarakat, dan mengakui, serta menghormati keberhasilan orang lain.
13. Bersahabat/Komuniktif. Tindakan yang memperlihatkan rasa senang berbicara, bergaul, dan bekerja sama dengan orang lain.

14. Cinta Damai. Sikap, perkataan, dan tindakan yang menyebabkan orang lain merasa senang dan aman atas kehadiran dirinya.

15. Gemar Membaca . Kebiasaan menyediakan waktu untuk membaca berbagai bacaan yang memberikan kebajikan bagi dirinya.

16. Peduli Lingkungan. Sikap dan tindakan yang selalu berupaya mencegah kerusakan pada lingkungan alam di sekitarnya, dan mengembangkan upaya-upaya untuk memperbaiki kerusakan alam yang sudah terjadi.

17. Peduli Sosial. Sikap dan tindakan yang selalu ingin memberi bantuan pada orang lain dan masyarakat yang membutuhkan.

18. Tanggung-jawab. Sikap dan perilaku seseorang untuk melaksanakan tugas dan kewajibannya, yang seharusnya dia lakukan, terhadap diri sendiri, masyarakat, lingkungan (alam, sosial dan budaya), negara dan Tuhan Yang Maha Esa (Puskur, 2010).

Membiasakan 18 karakter itu tidak mudah tetapi setidaknya guru dapat menerapkan dalam proses pembelajaran terutama guru matematika. Salah satu contoh penerapan karakter religius. Penerapan ini disamping guru menyampaikan dengan salam, tetapi bisa juga ketika siswa yang diajarkan beragama islam maka guru bisa mengkaitkan materi yang akan dibahas dengan hadits atau alquran yang berkaitan dengan materi tersebut. Misalnya dalam menghitung luas bangun datar segitiga dan segiempat maka guru bisa menerapkan prinisp pembagian waris yang bisa dikaitkan dengan materi agar 
pemberian waris sesuai dengan ketentuan islam, sehingga keadilan bisa diberikan kepada penerima waris tersebut. Itulah salah satu contoh penerapan karakter religius dalam pembelajaran matematika di kegiatan pendahuluan.

Pendidikan karakter juga bisa diberikan ketika guru melaksanakan pembelajaran terutama pemberian masalah untuk dipecahkan oleh siswa baik kelompok maupun perorangan. Seperti contoh soal di bawah ini:

Sebuah balok memiliki volume $384 \mathrm{~cm}^{3}$ , carilah kemungkinan-kemungkinan dari ukuran panjang, lebar dan tinggi rusuk balok tersebut, minimal 2 ukuran (Andiyana, M. A., Maya, R., \& Hidayat, W., 2018). Melalui soal tersebut dapat diterapkan beberapa karakter yang jika didesain oleh guru hasilnya bisa maksimal, karakter yang bisa diterapkan adalah sebagai berikut:

\section{Karakter Disiplin dan Kerja Keras}

Karakter ini erat kaitannya dengan kemampuan guru mampu mengelola dengan baik sikap disiplin dan kerja keras siswa dalam menjawab soal tersebut. Kerja keras perlu ditanamkan agar siswa terbiasa dalam kehidupan sehari harinya. Disiplin dapat dilakukan dengan cara memberikan waktu dalam pengerjaan soal tersebut.

\section{Karakter Kreatif dan Mandiri}

Karakter kreatif penting apalagi menghadapi era persaingan yang sangat ketat. Secara tidak langsung siswa diajarkan kreatif melalui menjawab soal tersebut karena harus memberikan jawaban lebih dari satu soal, mandiri dapat dilatih jika guru memerintahkan siswanya agar menjawab sendiri tanpa mencontek kepada orang lain.

Karakter Rasa Ingin Tahu dan Peduli Sosial

Karakter ini bisa terlihat jika guru terbiasa dalam memberikan soal yang sifatnya open ended yaitu soal dengan berebagai alternatif jawaban. Ini penting karena rasa ingin tahu yang tinggi dapat bermanfaat bagi siswa terutama ketika dihadapkan pada sesuatu yang baru, peduli sosial bisa kita tanamkan melalui kegiatan diskusi dimana antara siswa harus saling membantu satu sama lainnya.

\section{KESIMPULAN}

Melalui kajian dan analisis dengan penelaahan secara mendalam kajian teori maka pembelajaran matematika bisa menumbuhkan karakter pada diri siswa. Karakter diperlukan agar siswa mampu menjadi manusia yang cerdas dan baik. Selain itu karakter juga diperlukan sebagai modal dalam menghadapi era digital dengan persaingan yang ketat. Pembelajaran matematika bisa menjadi sarana dalam membiasakan pendidikan karakter yaitu melalui pembelajaran yang didalamnya diberikan soal pemecahan masalah. Pemberian karakter ini diharapkan menjadi kebiasaan dalam diri siswa sehingga siswa memiliki karakter yang baik.

\section{REFERENSI}

Amri, S., Jauhari, A., \& Elisah, T. (2011). Implementasi Pendidikan Karakter dalam Pembelajaran: Strategi Analisis dan Pengembangan Karakter Siswa dalam Proses Pembelajaran. Jakarta: Prestasi Pustakarata.

Andiyana, M. A., Maya, R., \& Hidayat, W. (2018). Analisis Kemampuan Berpikir Kreatif Matematis Siswa SMP Pada Materi Bangun Ruang. JPMI (Jurnal Pembelajaran Matematika Inovatif), 1(3), 239-248.

Cook, W. (2011). In Pursuit of the Traveling Salesman: Mathematics at the Limits of. Princeton NJ: Princeton University Press. 
Csicsery, G. (2008). Hard Problems. the Road to the World's Toughest Math Contest. Washington DC: Mathematical Association of America.

Devlin, K. J. (2012). Introduction to Mathematical Thinking. Palo Alto CA: published by Keith Devlin.

Fahmi, F.Y. and Hidayati, T., 2016. Gambaran self care status cairan pada pasien hemodialisa (literatur review). Care: Jurnal Ilmiah Ilmu Kesehatan, 4(2), pp.53-63.

Farida, S. (2016). Pendidikan karakter dalam prespektif islam. KABILAH: Journal of Social Community, 1(1), 198-207.

Ramdhani, M. A. (2017). Lingkungan pendidikan dalam implementasi pendidikan karakter. Jurnal Pendidikan UNIGA, 8(1), 28-37.

Sudrajat, A. (2011). Mengapa Pendidikan Karakter?. Jurnal Pendidikan Karakter, 1(1).

Suyata. 2011. "Pendidikan Karakter: Dimensi Filosofis", dalam Darmiyati Zuchdi (ed.). 2011. Pendidikan Karakter dalam Perspektif Teori dan Praktik. Yogyakarta: UNY Press.

Zubaedi. (2011). Desain Pendidikan Karakter: Konsepsi dan Aplikasinya dalam Lembaga Pendidikan. Jakarta: Kencana. 